$\xi=-1$ 囬

\title{
Florence and the river: new urban perspectives
}

\author{
Francesco Alberti ${ }^{1 *}$, Raffaele Paloscia ${ }^{2}$ \\ ${ }^{1}$ Department of Architecture, University of Florence \\ ${ }^{2}$ Department of Architecture, University of Florence \\ *Corresponding author E-mail: francesco.alberti@unifi.it
}

\begin{abstract}
The upgrading of riverfronts is a theme that has long played a central role in the renewal programs of large, medium and small cities throughout Europe. The case study presented in this paper is Florence, whose Roman origins and development, from the Middle Ages to today, are closely linked to the Arno River, which runs from east to west. After briefly reviewing some salient moments in the history of the relationship between the city and the river, the paper illustrates some research and projects carried out within the Department of Architecture of the University of Florence, focused on the role that Arno can still play in the future of the Florentine metropolitan area, as a catalyst for interventions aimed at improving urban sustainability, livability and resilience to climate change.
\end{abstract}

Keywords: Florence; Riverfronts; Urban Planning; Urban Sustainability; Urban Regeneration.

\section{Introduction}

This paper concerns Florence, specifically the relationship between the city and the river Arno, which crosses it from east to west.

Arno was one of the main factors of the very first settlement location in the area with the building of the Roman town, that is the starting point of the history of Florence. In the following centuries it strongly contributed to shape the city, becoming an essential feature of its urban landscape, as we know it at present time.

Nowadays, the river and its riversides still represent both a structuring feature and a multifunctional infrastructure of Florence metropolitan area, especially westwards the city center, where the fluvial plain is wider and major transformations occurred in the last five decades. Moreover they may play a strategic role in the next future, in the perspective of making Florence a more sustainable and livable city.

On this regard, the paper intends to briefly show how the Department of Architecture of the University of Florence has been an important actor in the debate about the future of the city and the metropolitan area, either providing professional consulting to the local government, or calling upon it with studies, proposals, workshops, etc..

\section{The shaping of Florence along the river: from the Medieval city to the $19^{\text {th }}$ Century Italian Capital}

After a long, and in some periods prosperous time since its foundation in 59 b.C., the configuration of the central area of Florence was fixed in the days of its greatest demographic expansion of the pre-industrial age, that is at the beginning of the 14th century, when its population exceeded 130.000 . Then, a new town walls circle was built, much wider than the previous one, which already ran on both sides of the river Arno. Four existing bridges linked the two parts of the city, the oldest of which ("Ponte Vecchio") located almost exactly in the place of the first natural ford used by the Romans [1]. These walls have been the town boundaries for 500 years and more, embracing the fabric of the original historic center, listed in the UNESCO World Heritage, that is still visible today.

In fact, we must wait until the second half of the 19th century to see the city grow beyond such boundaries.

At that time Florence became, for a short season (1864 to 1871), the capital of the young unified kingdom of Italy, after Turin and before the conquer and annexation of Rome, the natural capital of Italy, but still capital of the Papal States.

Neoclassic architect Giuseppe Poggi was charged with the responsibility of a plan whose chief aim was to display the new status of the city, according to the idea of an European capital intended to host a fast growing population and with an internationally recognizable image.

Poggi's Plan was produced and partly implemented from 1864 onwards - a typical product of 19th Century urban culture, whose models were Hausmann's Plan for Paris and the Vienna Ring Plan, although at a more modest scale [2]. It proposed the filling of the empty areas inside the perimeter of the walls and residential expansions beyond it, mostly concentrated on the north, where a large parade ground ("Campo di Marte") was also located - all that within a geometric layout. Its key feature was a new boulevards ring, that replaced the ancient walls of the Arno northern side, demolished for that purpose: a very common intervention of urban renewal in European cities of the time, connected with the construction of new transport infrastructures (railways or roads).

South of the river, the boulevards wound along the hills in a romantic promenade, broken by the picturesque Piazzale Michelangelo - a wide terrace especially designed in order to offer the most stunning view on the city and Arno River, fixing it as the "official" panorama of Florence, inspiring pride in the citizens of the newborn nation as well as international admiration. It is one of the 
most famous urban views all over the world (Fig. 1), with the river and its sequence of bridges in the foreground, the northern hills in the background, and the Renaissance city in-between, with its unique skyline, jagged of towers dominated by Brunelleschi's Dome - indeed a successful operation of urban marketing avantla-lettre.

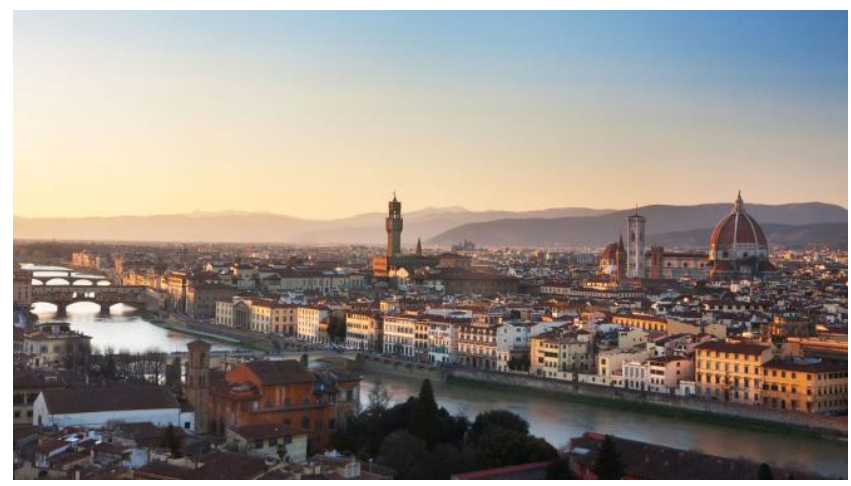

Fig. 1: View of Florence from Piazzale Michelangelo

By pursuing the aim of creating a new urban aesthetic [3], Poggi gives the river a major role, turning it from utilitarian resource into iconic feature of the city-scape, both in long and short distance views.

At the level of the city, new public walks created on the riversides (the Lungarni), protected by brick parapets and lit by cast iron streetlamps, became an open-air stage for the society of the time. That was a dramatic change in the urban structure, as well as in the relationship between the city and the river. Until then, there had been no mediation between the back facades of the buildings and the natural riverbanks, which were a working site for diggers, washerwomen, fishermen, and a dangerous place when rain was copious, because of the torrent-like behaviour of river Arno.

On the north-west, the Lungarni promenade was continued, crossing the boulevards built on the previous city walls grounds, within a wide landscape garden along the river - the Cascine Park. The area was originally a farm and hunting preserve of the Medici family, which had been opened to public since the beginning of the 19th Century by the sister of Napoleon, Elisa Bonaparte, before the Municipality of Florence bought it.

As we see in all post-unity maps (Fig. 2), one track of the railway linking Florence with the harbor of Leghorn runs along the border of the Cascine Park, creating a strong barrier on the north, which still exists. The first Florentine railway station - Leopolda - was located next to the monumental entrance to the park designed by Poggi, immediately outside the perimeter of the ancient walls.

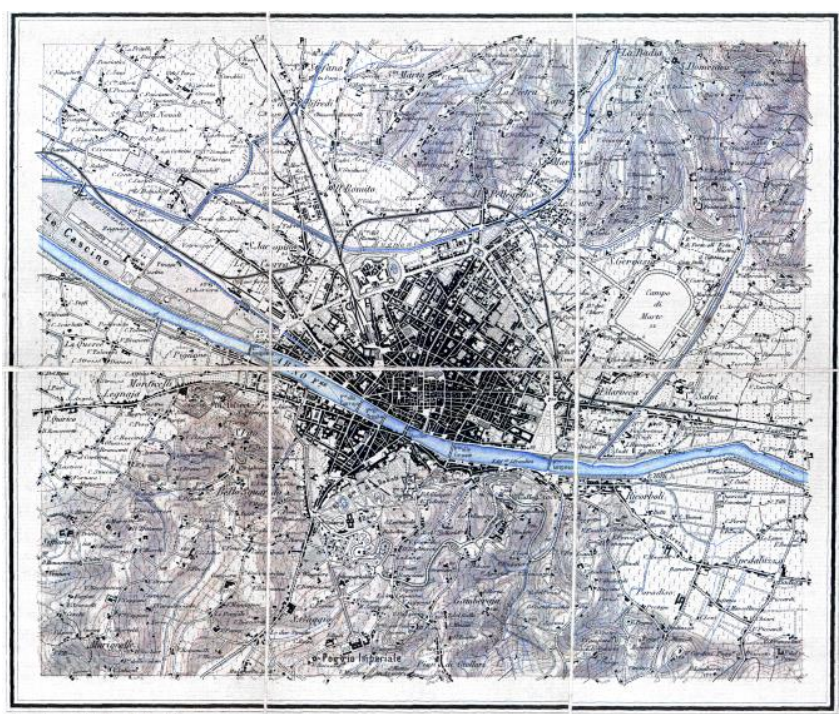

Fig. 2: Map of Florence (1871)
By the beginning of the new century, the Cascine Park has become, at a smaller scale, what Bois de Boulogne was for Paris: that is the theater of a vibrant social life, public events, romantic walks and sport activities in their early form (Fig. 3).

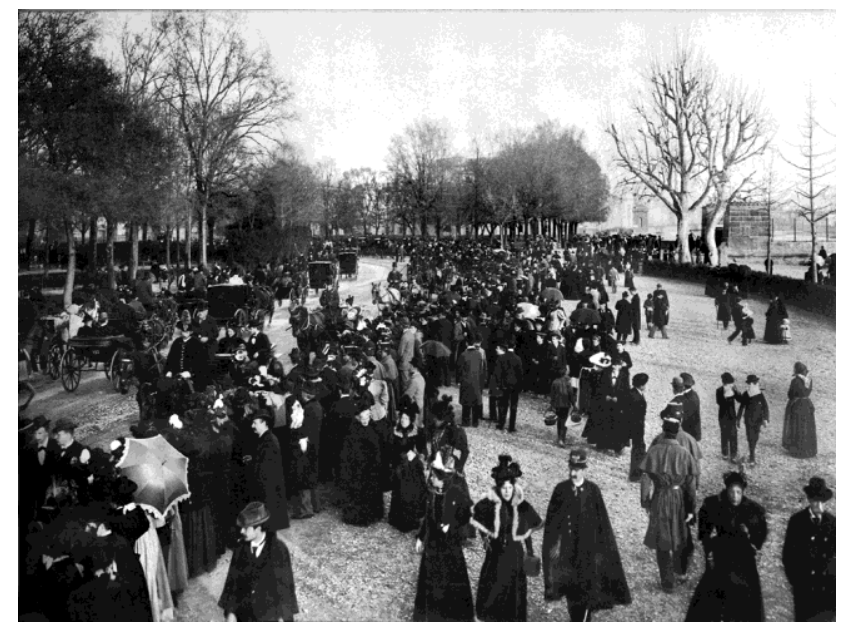

Fig. 3: The Cascine Park at the end of 19th Century

\section{Florence and the river: from the turn of modernity to the contemporary city}

One-hundred-fifty years later, the Cascine Park is still a living place (Fig. 4), especially in the weekends, and the most beloved park by bikers, skaters and joggers in the city. It hosts summer events, temporary funfair, a big weekly open-air market, horse races, sports meetings and so on.

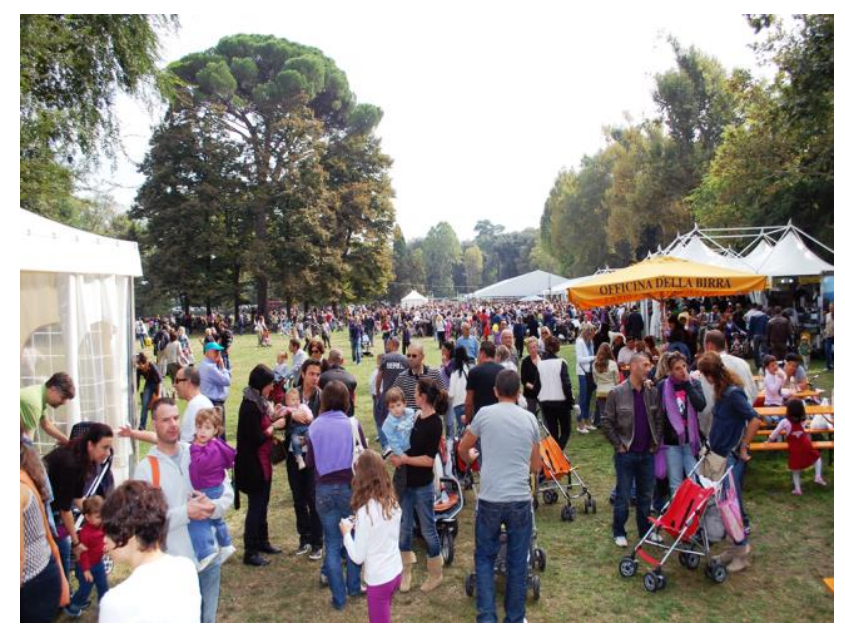

Fig. 4: The Cascine Park today

Of course in the meantime many things have occurred, changing and reshaping the interface city-river. We will just mention some major facts, whose consequences continue to be felt.

\subsection{War and reconstruction}

At the end of World War II, most destruction caused by the German troops during their northwards retreat took place along the riversides, in their attempt to prevent Americans from crossing Arno. All bridges were blown up by mines, except Ponte Vecchio, whose ends were blocked by the ruins of the surrounding medieval buildings (Fig. 5).

The following wide debate over reconstruction turned into very poor results. The proposal by Giovanni Michelucci, one of the most prominent figures of Twentieth-Century Italian architecture, for a radical redevelopment of the destroyed riverfront with ter- 
raced buildings and elevated squares was rejected by the City in favour of a more traditional way of building. At the end, the comprehensive reconstruction plan for the Ponte Vecchio area just followed previous property divisions, with a building density even higher than the historic urban fabric, in compliance with landlords' interests [4]. The original pattern of little arts and crafts laboratories was replaced by banks, restaurants, offices and other more profitable functions. This may seem negligible compared, for instance, to the redevelopment of Saint Paul's area in London, or those of many German city centers. Nevertheless, in the fragile balance of medieval Florence it was a major mistake.

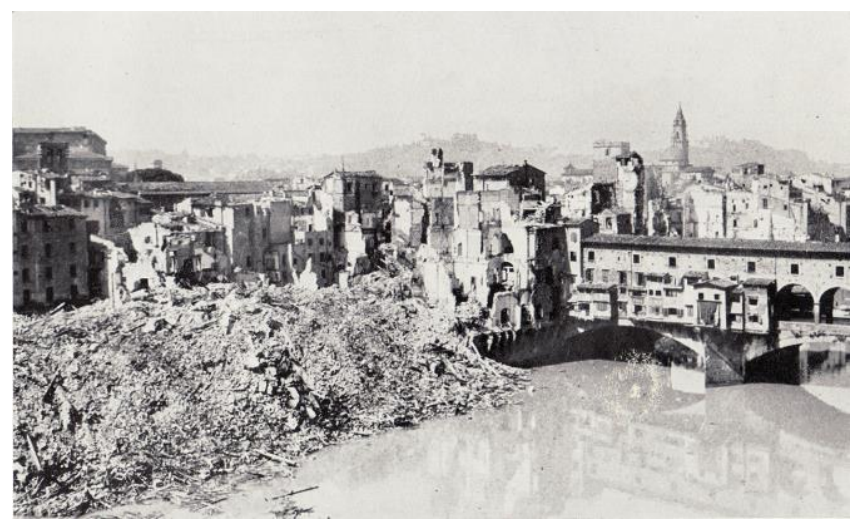

Fig. 5: Ponte Vecchio and the surrounding landscape of ruins at the end of World War II

\subsection{The "Florence Flood"}

On 4th November 1966, a devastating flood of the Arno caused new widespread destruction [5]. The images of the monuments under the water keep being world-famous (Fig. 6).

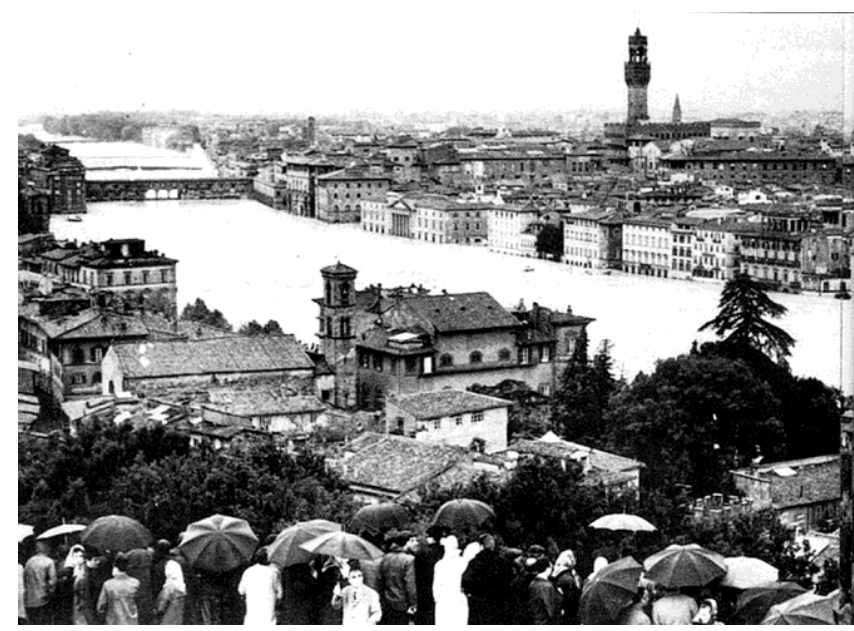

Fig. 6: The flood of Florence, in November1966. View from Piazzale Michelangelo

Besides the damages on urban structures, cultural heritage, businesses , many of which moved away from the city, this event caused the complete loss of confidence of Florence people on their river. That happened in a more drastic way than in the past, when the fear of recurring floods (sometimes catastrophic, like in 1557 and 1844) was balanced with the essential needs met by the river in a pre-industrial society.

After modernity had already swept off many traditional riverine activities, like sand-diggers or washerwoman, also everyday life scenes like children fishing or bathing in the Arno, still very usual in the 50ties, could no more be seen after the 1966 flood.

Just recently, after a big dam upstream of the city has become operational, and quite a lot of money has been invested in water purification and riverbanks maintenance, the first signs of a return to the river shores can be appreciated, in terms of summer events concerts, temporary art installations, open-air cafés, etc. (Fig. 7).

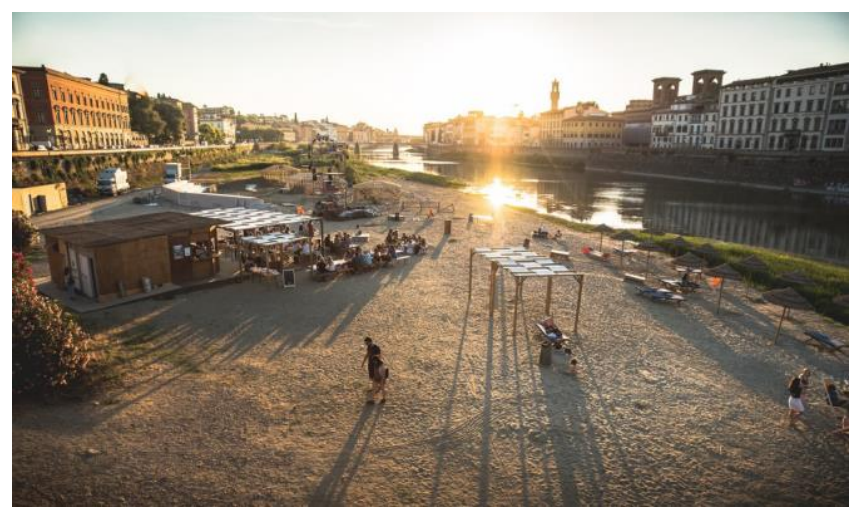

Fig. 7: Temporary beach in the center of Florence in summer 2017

\subsection{The growth boom}

Looking at Florence from Piazzale Michelangelo, visitors may assume that, apart from minor changes, the today's city is still rather similar to the one designed in Poggi's plan. In fact, the most relevant transformations, due to the Twentieth-Century urban growth in the Arno valley, are slightly visible in the distance or completely out of the frame. Moreover, a general land-use plan drown up in 1962 by architect Edoardo Detti luckily succeeded in preventing new buildings on the hills around Florence, dense of historic architectures and wonderful landscapes.

When the last city walls were demolished, paving literally the way for future developments, the Arno plain outside the city was still a continuous farmland, very similar to the rural landscape shown in a famous engrave by Giuseppe Zocchi one century before (Fig. 8).

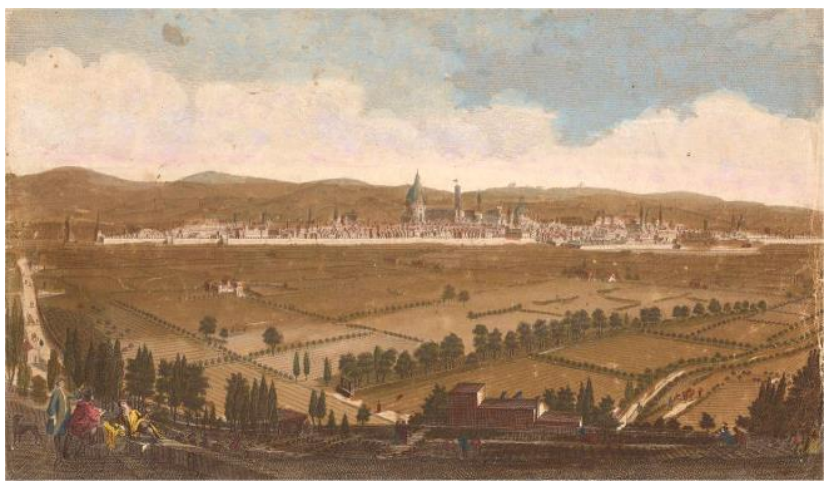

Fig. 8: "A General View of Florence taken from the Convent of the Capuchin Friars" (engrave by G. Zocchi, 1750)

The only exception were the railway tracks, which would become the axis of new urban developments in the industrial age, as well as the main regional roads did. Like in many other cities in Italy, after the stop of World War II, the urbanization process strongly accelerated in the Sixties, pushed by economic boom and massmotorization.

In a few decades a large metropolitan area (according to Italian standards), with a population of about one million, has silently grown westwards from the historic center, reducing agricultural land and other unbuilt areas to a patchwork pattern, that includes the Cascine Park and residual green areas and strips on both side of the river (Fig. 9).

\subsection{Lights and shadows of recent public works}

In the context of the metropolitan area, the Cascine Park still represent the main gate to the river between the historic and the contemporary city, spreading over the Arno plain. Some recent inter- 
ventions and projects have inconsistently weakened, on the one hand, and reinforced, on the other, the role and potential of such important urban node.

Inadequate design of mobility infrastructures have completely changed the interface between the river, the park and the city - so that a car tunnel and a new tramway line, which should provide an easy pedestrian accessibility and public transport to the park itself, have in fact destroyed the geometric unity of the place and the continuity of public space (Fig. 10).

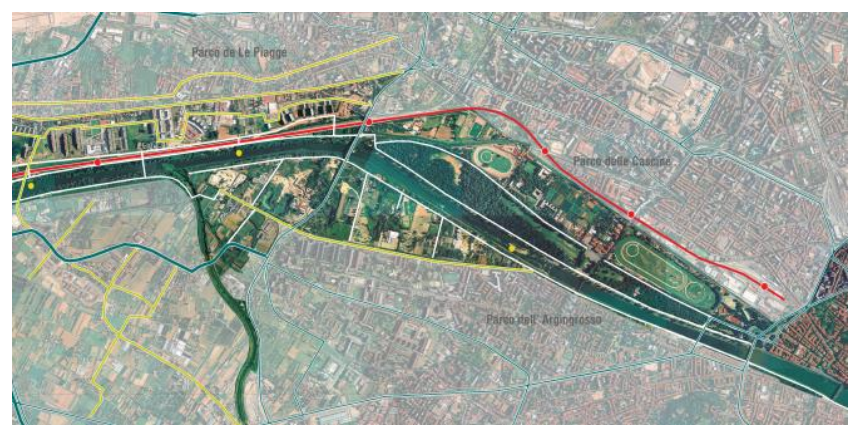

Fig. 9: City outskirts on both sides of the Arno River west from the historic center of Florence

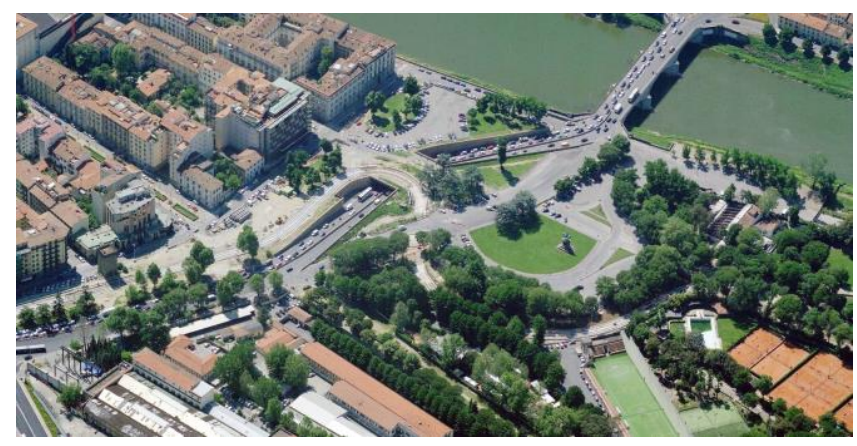

Fig. 10: The impact of contemporary infrastructures at the entrance of the Cascine Park

On the other side, new important cultural facilities have been located in the area: the old Leopolda Station was restructured in 1990 by architect Gae Aulenti into an art and convention venue (Fig. 11), while the back railway area has recently given ground to the new Opera House - one of the most innovative theaters in Europe and the second most important opera house in Italy after La Scala in Milan (Fig. 12). The open space in front of it - Piazza Vittorio Gui - is the biggest piazza in Florence.

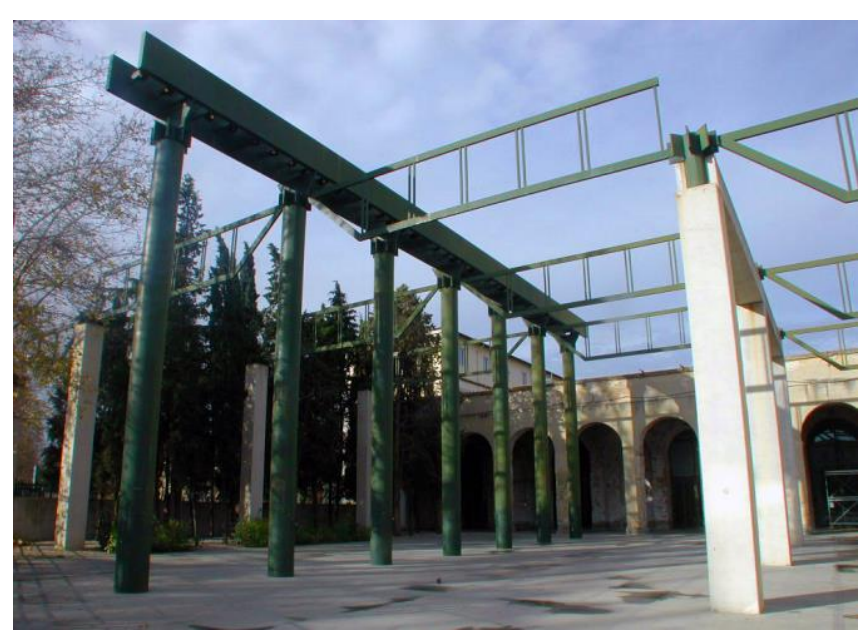

Fig. 11: The old Leopolda Station turned into a convention center (project by G. Aulenti, 1990)

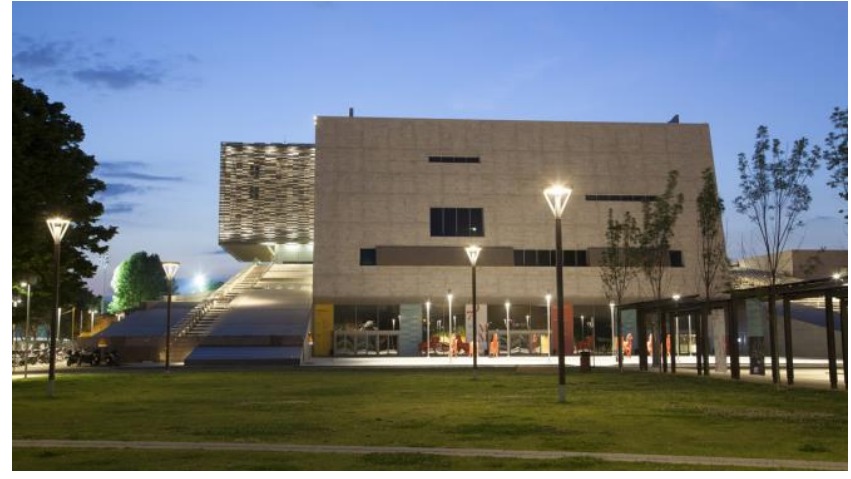

Fig. 12: The new Opera House of Florence, inaugurated in 2014 (project by Atelier BBPR)

\section{The river Arno, a resource for the future of the City: the contribution of the University of Florence to the urban debate}

In the whole, the presented city portrait describes a situation at the same time rich of opportunities and full of problems, that is an exciting challenge for spatial planners, landscapers and architects. The great opportunity for the city, despite the clutter of recentyears urbanization [6], is based on its persistent significant amount of green, unbuilt areas in the middle of the contemporary agglomeration. They include:

- the old Cascine Park with its immediate surroundings on the north side;

- a $3 \mathrm{~km}$ strip, connected with the Cascine Park, between the Arno and the railway embankment, aside a social housing development, Le Piagge;

- a wide overflow basin on the other side of the river, named Argingrosso (literally "big embankment"), which now hosts a mix of uses with no relationships to each other: little playgrounds, legal and illegal allotments, a gypsy settlement, a golf course, a few dispersed houses, a cement factory, etc..

The main problems concern hydraulic risk and the accessibility to these areas, very difficult from any side because of physical barriers such as railways and high river embankments. Inside connections are very weak too.

The projects of architects, urban designers and planners are taking advantage of the sites differences turning them altogether into a living multi-functional core for the contemporary city, physically connected with the historic one: a green heart which is comparable, in size and significance, with the old center (Fig.. 13).

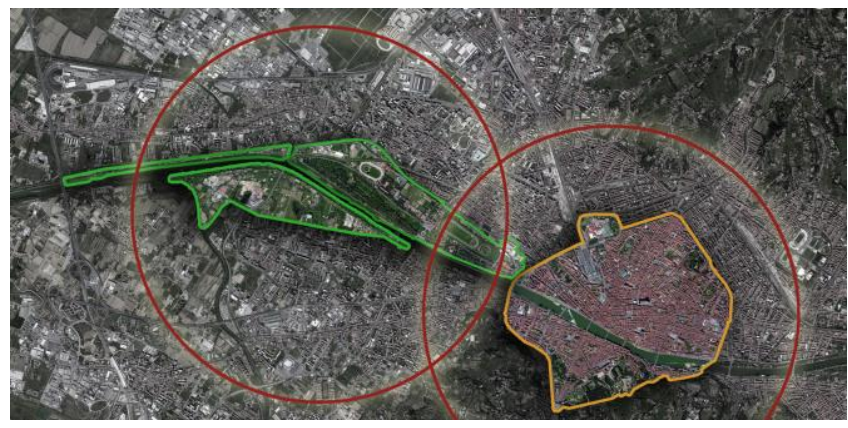

Fig. 13: A comparison between the dense historic center of Florence and the "empty" areas west from it, in the middle of the contemporary city, crossed by the river

While the $19^{\text {th }}$ Century Cascine Park should be restored and updated with compatible functions, the other parts could provide, inside a qualified natural context, leisure and cultural facilities at a metropolitan level, by accommodating those functions and structures which cannot find a suitable place in the existing dense city: 
an amusement park, a large concert and event area, a few urban beaches, a golf course, pick-nick areas, allotments, and so on.

We can say that, as in the past the river was a primary feature for the founding and development of Florence, nowadays it may be the essential element federating the polycentric metropolitan settlement along a linear park system [7], served by the existing railway and improved bicycle paths - and potentially also by boat services.

The perspective is to create a great multifunctional park as an extension of the center of Florence. It implies an integrated project approach, which should deal with various technical problems - in the field of hydraulic safety, just to say one - from a multitasking and creative point of view, in order to fulfill all different needs by mean of urban and landscape design.

A participatory planning and design process will be also needed in order to give momentum and coordinate the action of different administrative bodies and agencies around a common goal and a common planning idea.

The next notes refer to works carried out by professors, researchers and students of the Department of Architecture of Florence University, as an example of multi-sectoral approach, as well as of the attitude of our school to join and animate the discussions on urban innovation in a context where history and tradition are still so important.

\section{1. "Great Cascine" proposal (1982)}

A study coordinated by Guido Ferrara, Professor in Landscape Architecture, on account of the Municipality of Florence [8], provided the very first vision, illustrated also by means of evocative eye-bird perspectives, for a greater Cascine Park including the facing area of the Argingrosso (Fig. 14). According to the study, the overflow basin on the southern riverbank should be turned into an insular multi-activity park by the digging of a water channel - a very suggestive solution to the problems of hydraulic safety that has been mistakenly abandoned in the following years.

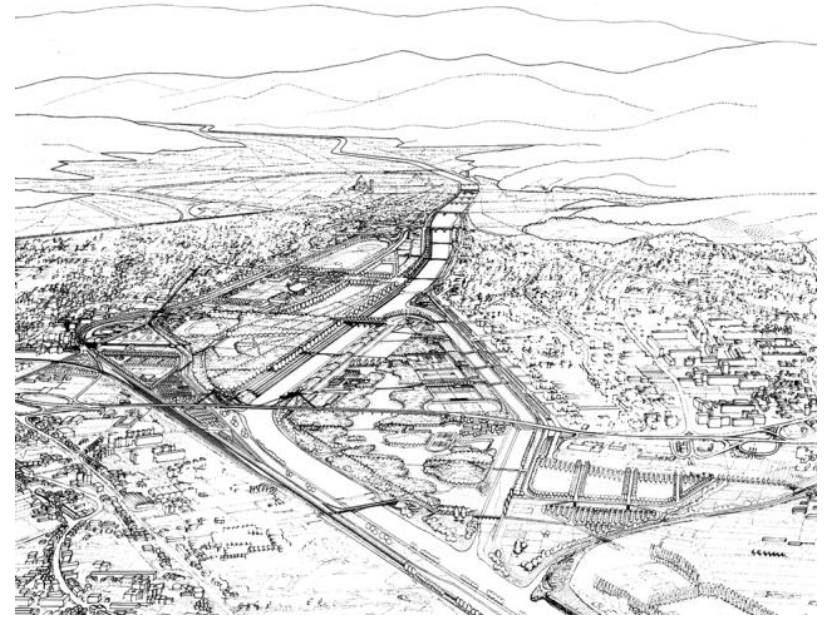

Fig. 14: "Great Cascine” proposal (G. Ferrara, 1982)

\section{2. "Riverlink project" for the Argingrosso area (2003- 2006)}

During the years following the "Great Cascine" proposal, the idea of doubling the park on the other side of the Arno has being kept as a goal for all city governments [9], even though no defined design has been unfortunately approved until now.

In 2003, a pilot scheme for the green area of Argingrosso drown up by Biagio Guccione, Professor in Landscape Design, was chosen by the City of Florence for joining the European project "Riverlink" on the revitalization of city-river interfaces [10] (Fig. 15).

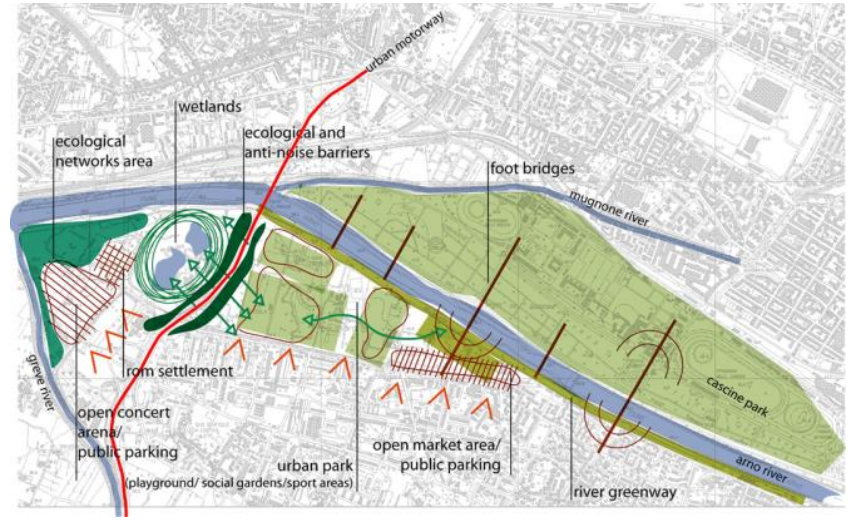

Fig. 15: "Riverlink project" for the area of Argingrosso (B. Guccione 2003-2006)

With a few resources made available by the EU, the reshaping of the river embankment, according to a landscaping point of view, could at least begin.

\section{3. "Beach of Florence" proposal at Le Piagge (2007)}

In the same year the City of Florence charged architect Giancarlo de Carlo with the master plan for the urban regeneration of Le Piagge, a deprived neighbourhood North-West from the Cascine Park [11] (Fig. 16). Four years later, in 2007, according to the recommendations in De Carlo's master plan for turning Le Piagge into a sort of contemporary garden city, a team of planners of the University of Florence (coordinated by Marco Massa and Francesco Alberti), developed the idea of equipping the neighbourhood with an urban beach, like in Paris, Berlin and many other European cities riverfronts. It was planned to be realized on the riverbank, opposite to the existing railway by means of simple earth works and the arrangement, during the summer season, of temporary structures for bars and other facilities [12]. The concept plan for the "Beach of Florence" was later furthermore developed in some graduate thesis on urban design (Fig. 17).

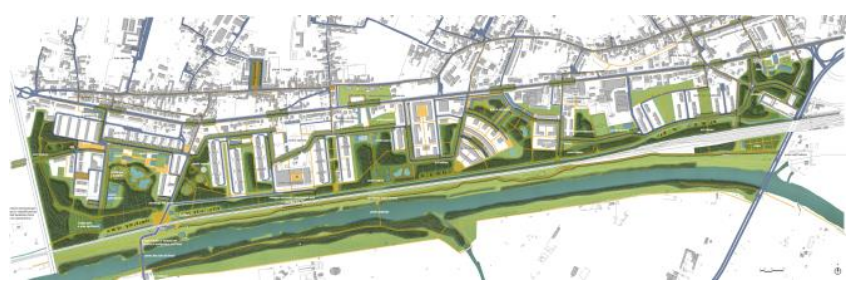

Fig. 16: Masterplan for the regeneration of the urban neighbourhood Le Piagge (G. De Carlo, 2003)

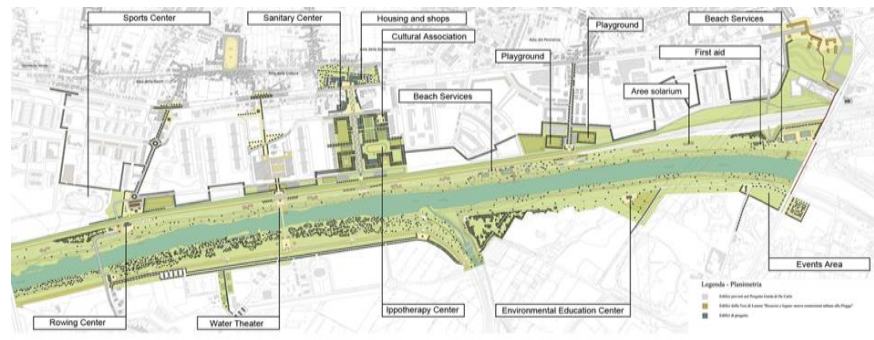

Fig. 17: Beach of Florence" proposal at Le Piagge (F. Alberti and M. Massa, with J. Carlini, 2007)

\subsection{Contributions to the new master plan for the "Great Cascine Park" (2012-2017)}

After so many false starts, in 2012 the Department of Architecture was requested by the city government to provide new ideas for a general master plan of the area. Because of that, groups of stu- 
dents in advanced classes have been addressed in the following years to seminar-workshops on this topic. The aim has been to tackle different kind of problems and opportunities, like the functional organization and accessibility to the park, which needed to be improved, or the mitigation of existing infrastructures inside a new arrangement of the interface between the park itself and the city (Fig. 18).

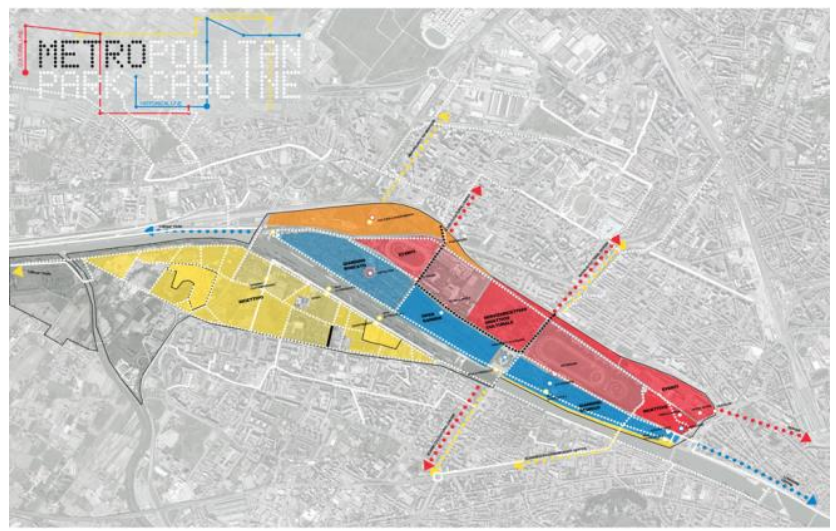

Fig. 18: The masterplan for the area of the "Great Cascine Park" proposed in a workshop of the School of Architecture of Florence (2014)

As far as the multi-activity area at the Argingrosso is concerned, different solutions compatible with its hydraulic function as overflow basin have been studied, such as the digging of new ponds for improving its water capacity inside a new natural environment (Fig.. 19), or, on the contrary, the creation of a very artificial landscape made of multi-functional platforms above the flood level (Fig. 20).
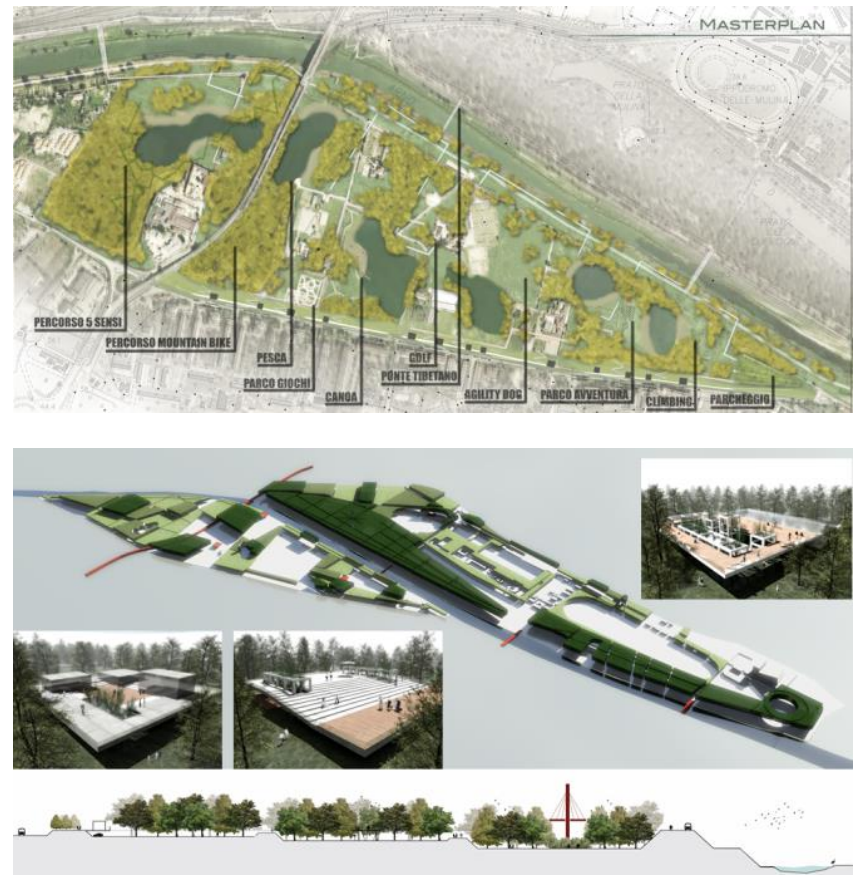

Figs. 19-20: Students' proposals for the Argingrosso area

While the masterplan finally approved by the City (Fig 21), which was designed by the équipe of prof. Fabio Lucchesi, incorporates many of the suggestions for the old park emerged from the workshop, 35 years after the "Great Cascine" proposal, the area of the Argingrosso is still waiting for a decision about its future use.

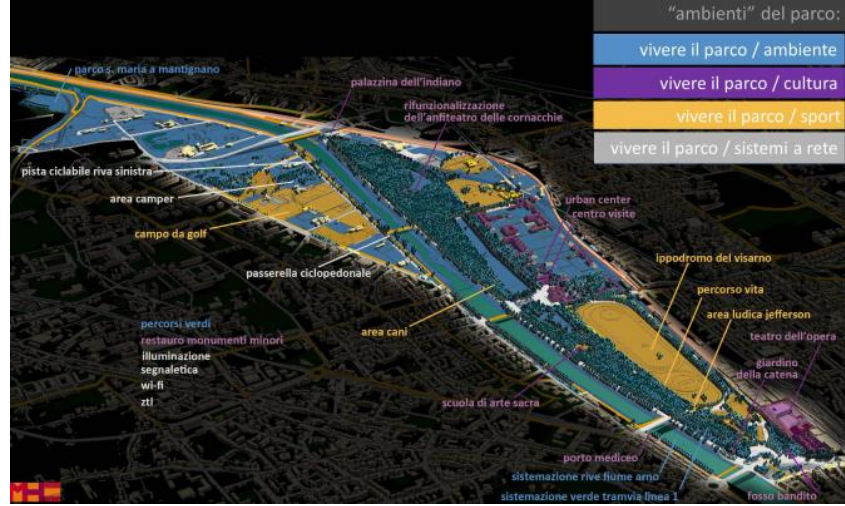

Fig. 21: The masterplan for the "Great Cascine Park" approved by the City (MHC, 2014)

\subsection{The Arno River as a blue-green infrastructure (2014-2017)}

More recently, the role of the Arno River as a multifunctional blue-green infrastructure has become topical as a consequence of the institution, according to an Italian national law, of the Metropolitan City of Florence (2014), which includes all municipalities once belonging to the Province [13], as well as of the celebrations for the 50th anniversary of the Florence Flood [14]. New crossdisciplinary researches at a wider scale have been carried out by two groups of the Department of Architecture as contributions to the definition of a comprehensive strategy for the sustainable development of the Metropolitan City. The application field of both researches is the alluvial plain southwest from Florence (Fig. 22), studied from different but complementary points of view.

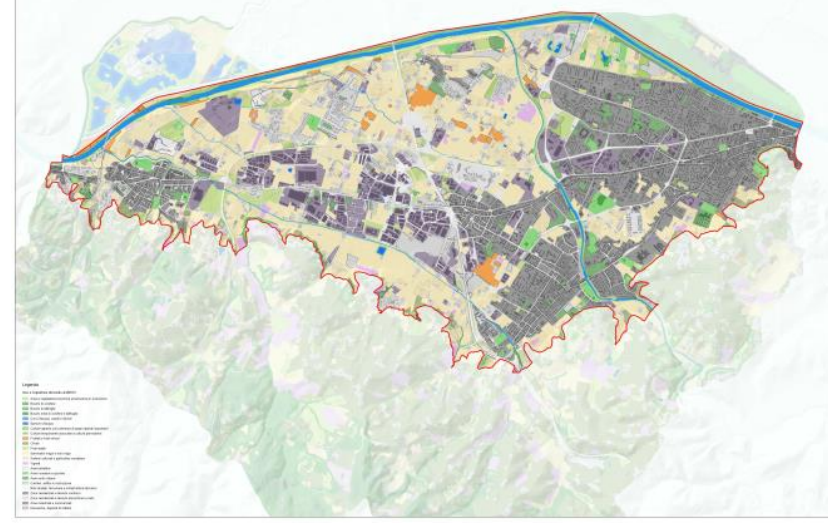

Fig. 22: Land use map of the plains SW from the center of Florence

On one side, the research "Cultivating with the Arno", coordinated by prof. Daniela Poli, is focused on the conservation, reclamation and extension of farmlands, in order to increase short-chain agricultural production and provide ecosystem services to the whole metropolitan area; on the other hand, the research "Adaptive design and technological innovations for resilient urban districts regeneration in climate change", coordinated by prof. Roberto Bologna as a part of a national research funded by the Italian Government, which involves six universities, looks at the historic and contemporary settlement spread over the plain as a significant territorial sample for innovative interventions of urban renovation, aimed at improving the livability of urban outskirts along with their resilience towards cloudbursts, flood and heat islands, whose risk is increased by climate change. 


\section{Conclusion}

The revitalization of urban riverfronts is one of the most relevant themes of the current cycle of transformations in the European cities. As the studies and projects mentioned above show, the theme crosses different needs and problems, which, depending on the circumstances, may play a more or less important role in defining strategies and projects. These include the protection from hydraulic and hydrogeological hazards, as well as the mitigation or adaptation to climate change; the upgrading or the creation of public spaces and facilities; urban embellishment as well the provision of eco-systemic services aimed at increasing urban sustainability. In contexts with a strong historical footprint, all these aspects have to be addressed in the light of a more general issue: how responding to the needs and expectations of contemporary life, looking at historical cities not only as open-air museums but also as evolving organisms in relationship with their surroundings, without jeopardizing their peculiar values, and assuming sustainability as a binding paradigm. To pursue this goal, a multidisciplinary and integrated approach to the various problems is needed, able to bring together all different sectoral contributions within an overall vision, combining scientific rigor and design sensibility. A strong public direction is essential as well. For their part, universities can play an important role in building visions and supporting decisions by putting in place the necessary skills.

In that light, we think that the debate on the future of Florence along the river Arno may be interesting not only at a local level.

\section{Acknowledgement}

The authors thank Iacopo Zetti for his suggestions and comments on the text, and all the colleagues at the Department of Architecture of Florence who provided materials of their works mentioned in the paper.

\section{References}

[1] Fanelli G., Le città nella storia d'Italia. Firenze, Laterza, RomeBari, (1989).

[2] Borsi F., La capitale a Firenze e l'opera di Poggi, Colombo, Rome, (1970).

[3] Agostini E.M., Giuseppe Poggi: la costruzione del paesaggio, Diabasis, Reggio Emilia, (2002).

[4] Boggiano A., Foresi R., Zoppi M. (ed.), Firenze: la questione urbanistica. Scritti e contributi 1945-1975, Sansoni, Florence, (1982).

[5] Alexander D., "The Florence floods-What the papers said", Environmental Management, Vol.4, No.1, (1980), pp: 27-34.

[6] Giorgieri P. (ed.), Firenze: il progetto urbanistico. Scritti e contributi 1975-2010, Alinea, Florence, (2010).

[7] Ermini L., Ulivieri L. (ed.), Un parco fluviale per l'Arno, Edifir, Florence, (2006).

[8] Comune di Firenze, Progetto Grandi Cascine, Alinari, Florence, (1989).

[9] Comune di Firenze, Proceedings of the conference "Cascine giornate di studio", Florence, 8-9 October 1992, Officine Grafiche Stianti, San Casciano, Florence, (1993).

[10] Guccione B., Meli A., Risicaris G. (ed.), A networking experience for successful city-river interface, Edifir, Florence, (2008).

[11] De Carlo G., "Progetto guida per dell'ambito territoriale denominato Le Piagge", unpublished, (2003)

[12] Alberti F., Massa M.,'La città e il fiume: alla ricerca di una interfaccia amichevole", Testimonianze, Vol. 504-506, (2016), pp: 254-260.

[13] Città Metropolitana di Firenze, Rinascimento metropolitano. Piano Strategico 2030, Florence, (2017).
[14] Maccabruni L., Zarrilli C. (ed.), Arno: fonte di prosperità, fonte di distruzione. Storia del fiume e del territorio nelle carte d'archivio, Polistampa, Florence, (2016). 